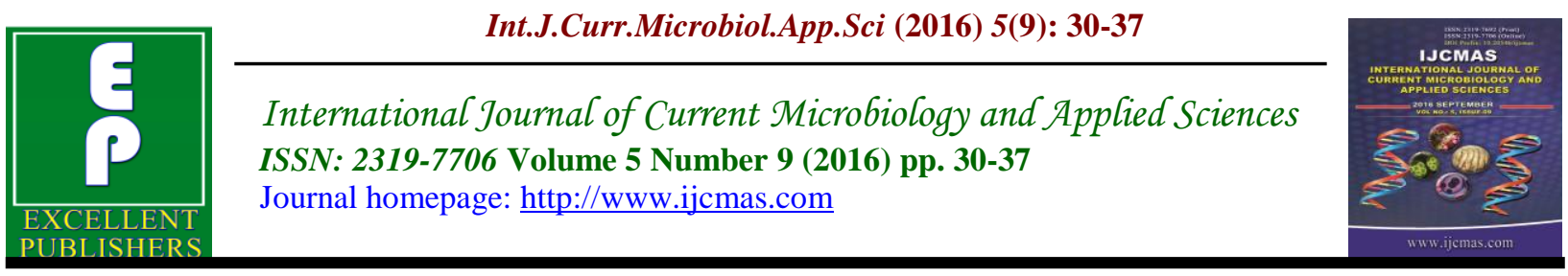

Original Research Article

http://dx.doi.org/10.20546/ijcmas.2016.509.004

\title{
Efficacy of Probiotics in Water Quality and Bacterial Biochemical Characterization of Fish Ponds
}

\author{
K. Sunitha* and P.V. Krishna \\ Department of Zoology and Aquaculture, Acharya Nagarjuna University, \\ Nagarjunanagar- 522510, A.P., India \\ *Corresponding author
}

\begin{tabular}{|c|c|}
\hline & A B S T R A C T \\
\hline $\begin{array}{l}\text { Ke y w or d s } \\
\text { Pond probiotics, } \\
\text { fish ponds, } \\
\text { nitrifying bacteria } \\
\text { and water quality } \\
\text { parameters, } \\
\text { biochemical } \\
\text { characterization. }\end{array}$ & \multirow{3}{*}{$\begin{array}{l}\text { The present study was aimed to know the efficacy of probiotics in bacteria } \\
\text { biochemical characterization (Nitrosomonas and Nitrobacters pecies) and } \\
\text { pathogenic bacteria (Pseudomonas species) were analysed water quality in fish } \\
\text { treated with pond probiotics. Two types of commercial probiotics were used i.e., } \\
\text { Aqua gut (fish) as feed probiotic-treatment- } 2 \text { and Nitro-PS+ Micro-Pro (fish) as } \\
\text { soil and water probiotics treatment-3 (manufactured by Asian Bio Tech, } \\
\text { Hyderabad, Andhra Pradesh, India).The fishponds stocked with catla (Catla catla) } \\
\text { rohu (Labeo rohita) and grass carp (Ctenopharyngodon idella) were selected and } \\
\text { are designated as control pond (T1), Treatment- } 2 \text { and Treatment-3. Treatment } 2 \\
\text { and } 3 \text { were treated with probiotics control pond without probiotic. The present } \\
\text { study revealed that the use of probiotics in experimental pond the beneficial } \\
\text { bacteria load ((Nitrosomonas and Nitrobacter species) is drastically increased but } \\
\text { decreased the level of pathogenic Pseudomonas species. The isolated probiotic } \\
\text { bacteria was identified by morphology and biochemical characterization. }\end{array}$} \\
\hline Article Info & \\
\hline $\begin{array}{l}\text { Accepted: } \\
\text { 07 August } 2016 \\
\text { Available Online: } \\
\text { 10 September } 2016\end{array}$ & \\
\hline
\end{tabular}

\section{Introduction}

In large-scale production facilities, aquatic animals are exposed to stressful conditions. The increased intensity of aquaculture has led to high number of disease outbreak with an increasing range of pathogens as a result in serious economic losses. (Verma and Gupta, 2015). Probiotics diminish the growth of pathogens and increase the growth of beneficial bacteria, leading to, improved water quality and healthier fish or prawn (Ninawe and Selvin, 2009; Chen and Hu, 2011). In aquaculture, water probiotics improve the quality of water and the pond bottom sediment thereby creating a stress free environment for the animal and thus improves its health (Moriarty et al., 2005). Feed probiotics keep the aquatic animals healthy in terms of weight, size and nutrition. In addition probiotics also protect the aquatic animals from different microorganisms and their virulence can also be controlled (Verchuere et al., 2000).

The researchers have been attempting to isolate beneficial bacteria from various sources like soil, water and animal gut to 
control disease causing pathogens in aquaculture systems (Austin and Day, 1990; Munro et al., 1995; Gomez-Gil et al., 2000; Ahmed et al., 2005; Kim et al., 2007 and Bestha Lakshmi et al., 2013). The recent attempt being made in the use of probiotic bacteria in aquaculture to improve water quality by balancing bacterial population in water and reducing pathogenic bacterial load. The present investigation was aimed to study the changes in water quality, bacteria load and biochemical characterization of bacterial isolates from water samples of Machilipatnam area in probiotic treated ponds and to compare the results with those of the untreated pond.

\section{Materials and Methods}

\section{Fishponds}

For the present study, the investigations were conducted from August 2012 to July 2013 in the culture ponds at Machilipatnam in Krishna District, Andhra Pradesh, India. The experimental ponds with water spread area of 2.5ha having depth of $1.5 \mathrm{~m}$ were chosen for this study. These three ponds are rectangular in shape having buds with coconut trees. All ponds are equal in size. The supplementary feed having $27.9 \%$ crude protein including, ground nut oil cake, rice bran, coconut oil cake, dry fish, vitamin and minerals premix. Then the ponds were applied with inorganic fertilizers, poultry manure and triple super phosphate at the rate of 8 and $15 \mathrm{~kg} / \mathrm{ha}$ respectively.

\section{Probiotics}

In the present investigation two types of commercial probiotics were used i.e., Aqua gut (fish) as feed probiotic-treatment-2 and Nitro-PS+ Micro-Pro (fish) as soil and water probiotics treatment-3 (manufactured by Asian Bio Tech, Hyderabad, Andhra Pradesh, India).

\section{Stocking of fish species in experimental ponds}

Two weeks after manuring, each pond was stocked with catla (Catlacatla), rohu (Labeorohita) and grass carp (Ctenopharyngodon idella) in the ratio $4: 6: 1$. The average body weight was recorded at the time of stocking.

\section{Water samples}

The present investigation, physico-chemical parameters of water and plankton were studied at fortnight intervals by collecting water sample in between 9 and 10 a.m. The physico-chemical parameters such as temperature, transparency, dissolved oxygen, $\mathrm{pH}$, nitrite, nitrate, ammonia, phosphorus and iron of water were estimated by following the methods suggested in APHA (1999).

\section{Bacteriological analysis}

The water samples were collected from probiotics-treated and control ponds in well cleaned, derived and sterile bottles. These bottles were sterilized at $121^{\circ} \mathrm{C}$ under pressure of $15 \mathrm{lbs}$ for 15 minutes. Column water samples were collected for the analysis if Pseudomonas and E. coli Whereas bottom waters for Nitrosomonas, Nitrobacter, after collection $1 \mathrm{ml}$ of the sample was transferred to sterile conical flask $(150 \mathrm{ml})$ containing $99 \mathrm{ml}$ of sterile diluents and serial dilution was performed to get $10^{-1}, 10^{-2}, 10^{-3}, 10^{-4}$ and $10^{-5}$ samples. Nitrosomonas species was enumerated by using Winogradsky medium phase-1 medium Whereas Nitrobacter species was enumerated by using Winogradsky medium phase- 2 medium. From the diluents $0.1 \mathrm{ml}$ of the sample was inoculated into the medium containing petri plates and were incubated at $28 \pm 2^{\circ} \mathrm{C}$ for $48 \mathrm{~h}$. Pseudomonas species was enumerated by using Pseudomonas base medium (Hi-media, 
Mumbai) In these plates, $0.1 \mathrm{ml}$ of the sample was inoculated and incubated at $37^{\circ} \mathrm{C}$ for $24 \mathrm{~h}$. After the incubation, the colonies were counted and expressed as $\mathrm{cfu} / \mathrm{ml}$ (colony forming unit/ml) for water sample.

\section{Identifications of the organisms}

The isolated probiotic bacterium was identified by morphology and biochemical characterization methods.

\section{Morphological characterization}

Morphology and culturecharacteristics such as shape, color, size, edge elevation, transparency and surface texture. To identify the selected bacterial isolates to genus or species, the purified isolates were subjected to observe the cell shape, motility, flagellation, spores and encapsulation and Gram staining.

\section{Biochemical characterization}

The isolates were then subjected to biochemical tests (Indole, methyl red, voges-proskauer, citrate utilization, hydrogen sulfide, starch hydrolysis, oxidase and catalase) following biochemical tests were carried out according to the method described by Cappuccino and Sherman (1996) and Bergey's manual (Holt et al., 1994)

\section{Simple staining}

For simple staining, the bacterial smears were treated with crystal violet (60 seconds) and rinsed with distilled water. Then smears were air dried and observed under microscope.

\section{Gram staining}

A thin smear of the isolate was made on a clean glass slide and heat fixed. Then the smear was stained with crystal violet for 1 minute and then washed with water, gram's iodine was added for 1 minute and decolorized with alcohol. After decolourization the smear was counter stained with saffranin for 1 minute. Finally the smear was washed with water and air dried. Then the slide was observed under the microscope.

\section{Indole Production test}

One percentage peptone broth was prepared, sterilized and incubated with the isolated colonies and incubated at $37^{\circ} \mathrm{C}$ for $48 \mathrm{~h}$. After incubation $1 \mathrm{ml}$ of Kovac's reagent was added and gently shaken. The results were observed after allowing the tubes to stand. A cherry red ring indicates the positive reaction.

\section{Methyl Red Test}

MR-VP broth was prepared, sterilized and incubated with the isolates, 5 drops of methyl red indicator was added and the tubes were observed for a color to red that indicates a positive reaction.

\section{Voges-ProskauerTest}

MR- VP broth was prepared sterilized and incubated with the isolated, incubated at 37 for $48 \mathrm{hr}$. After incubation few drops of Baritt's reagent B and A were added and the result noted. Development of crimson to pink color indicates a positive reaction incubated with the isolates, incubated at 37 for $48 \mathrm{hr}$.

\section{Citrate Utilization Test}

Simmon's citrate agar medium was prepared, sterilized and transferred aseptically to the test tubes and slat was prepared. The isolated colonies were streaked on the surface of the slat and 
incubated at $37^{\circ} \mathrm{C}$ for 24 hours. A change in green color to Prussian blue indicates the positive results

\section{Starch Hydrolysis test}

Starch agar medium was prepared and transferred aseptically into sterile petridish. The isolated colonies were streaked on starch agar plates and incubated at $37^{\circ} \mathrm{C}$ for $48 \mathrm{hr}$. the plates were flooded with Gram's Iodine. Amylase production was indicated by colorless zone surrounded by bacteria and rest of the plate appeared purple.

\section{Oxidase test}

A drop of $1 \%$ Kavac's regent after a loop and pick a well- isolated colony from a fresh (18 to 24 hour culture) bacterial plate and rub on to treated filter paper. Color changes to dark purple or blue after 30 s to $1 \mathrm{~min}$ is an evidence that the result is positive.

\section{Catalase Test}

A clean glass slide was taken and a drop of culture suspension was placed on the glide. To the culture few drop of hydrogen peroxide was added. A positive reaction indicates the release of air bubbles from the suspension

\section{Results and Discussion}

Probiotic bacteria are also known to upgrade the water quality in many ways. The probiotics entertained a major role in maintain optimum water quality indices especially dissolved oxygen, ammonia, nitrite, nitrate and phosphates thought the culture period.

Table.1 Physico-chemical parameters of water (Mean \pm SD and Ranges) in three treatments

\begin{tabular}{|l|ll|ll|ll|}
\hline Physico-chemical & \multicolumn{3}{|c|}{ Control (T1) } & \multicolumn{2}{c|}{ Treatment-2 } & \multicolumn{2}{c|}{ Treatment-3 } \\
parameters & Mean \pm SD & Range & Mean \pm SD & Range & Mean \pm SD & Range \\
\hline Water temperature $\left({ }^{0} \mathrm{C}\right)$ & $28.63 \pm 1.58$ & $25.5-30.5$ & $28.21 \pm 2.24$ & $25.0-31.5$ & $28.25 \pm 1.95$ & $25.0-31.5$ \\
Transparency(cm) & $35.25 \pm 5.33$ & $29.0-45.0$ & $33.17 \pm 3.27$ & $28.0-40.0$ & $32.08 \pm 3.26$ & $28.0-40.0$ \\
Dissolved oxygen(mg/L) & $5.48 \pm 0.47$ & $4.8-6.2$ & $5.30 \pm 0.72$ & $4.2-6.2$ & $5.88 \pm 0.45$ & $5.0-6.4$ \\
pH & $8.12 \pm 0.44$ & $7.2-8.6$ & $8.32 \pm 0.27$ & $8.0-8.6$ & $8.29 \pm 0.25$ & $8.0-8.6$ \\
Ammonia (mg/L) & $0.52 \pm 0.07$ & $0.44-0.64$ & $0.40 \pm 0.06$ & $0.27-0.46$ & $0.35 \pm 0.06$ & $0.26-0.49$ \\
Nitrite(mg/L) & $0.07 \pm 0.02$ & $0.01-0.09$ & $0.06 \pm 0.02$ & $0.02-0.07$ & $0.04 \pm 0.02$ & $0.01-0.07$ \\
Nitrate(mg/L) & $0.23 \pm 0.07$ & $0.12-0.36$ & $0.31 \pm 0.10$ & $0.12-0.47$ & $0.49 \pm 0.06$ & $0.41-0.60$ \\
Orthophosphate(mg/L) & $0.59 \pm 0.10$ & $0.42-0.75$ & $0.14 \pm 0.08$ & $0.29-0.56$ & $0.47 \pm 0.09$ & $0.32-0.59$ \\
Iron(mg/L) & $0.37 \pm 0.06$ & $0.28-0.51$ & $0.27 \pm 0.05$ & $0.21-0.35$ & $0.32 \pm 0.07$ & $0.21-0.41$ \\
\hline
\end{tabular}

Table.2 Biochemical tests conducted for identification of bacteria isolated in three treatments

\begin{tabular}{|l|l|l|l|l|l|l|}
\hline \multirow{2}{*}{ Biochemical tests } & \multicolumn{3}{l|}{ Nitrosomonas $\mathrm{sp}$} & \multicolumn{3}{l|}{ Nitrobacter $\mathrm{sp}$} \\
\cline { 2 - 7 } & T1 & T2 & T3 & T1 & T2 & T3 \\
\hline Indole test & - & - & - & - & - & - \\
Methyl red test & + & + & + & + & + & + \\
Hydrogen sulfide test & + & + & + & + & + & + \\
Oxidase test & + & + & + & + & + & + \\
Gram staining & $+/$ rods & + /rods & $+/$ rods & $+/$ rods & $+/$ rods & $+/$ rods \\
\hline
\end{tabular}


Table.3 Biochemical tests conducted for identification of bacteria isolated in three treatments

\begin{tabular}{|l|l|l|l|}
\hline \multirow{2}{*}{ Biochemical tests } & \multicolumn{3}{|l|}{ Pseudomonas $\mathrm{sp}$} \\
\cline { 2 - 4 } & T1 & T2 & T3 \\
\hline Indole test & - & - & - \\
Methyl red test & - & - & - \\
Voges-Proskauer test & - & - & - \\
Citrate utilization test & + & + & + \\
Carbohydrate metabolism test & - & - & - \\
Gelatin hydrolysis test & + & + & + \\
Hydrogen sulfide test & + & + & + \\
Urease test & - & - & - \\
Starch hydrolysis test & - & - & - \\
Oxidase test & - & - & - \\
Catalase & + & + & + \\
Gram staining & $+/$ rods & + /rods & + /rods \\
\hline
\end{tabular}

Fig.1 Bacterial population in T1, T2 and T3

\section{a. Nitrosomonas population}

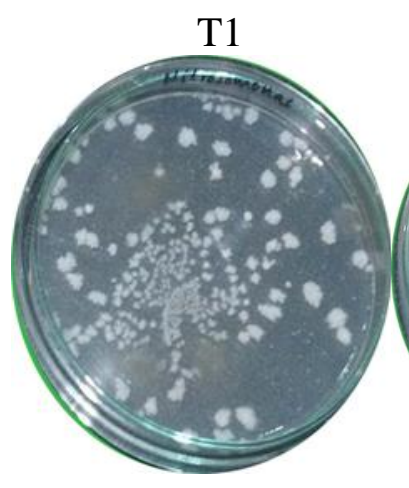

$\mathrm{T} 2$

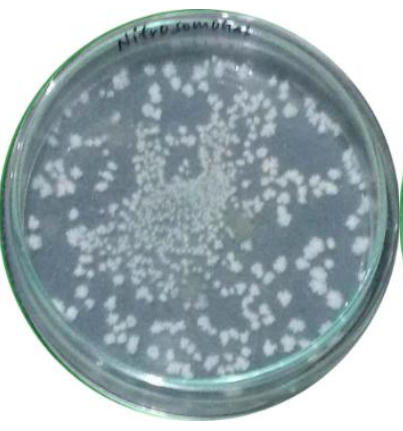

b. Nitrobacter population

$\mathrm{T} 1$

$\mathrm{T} 2$

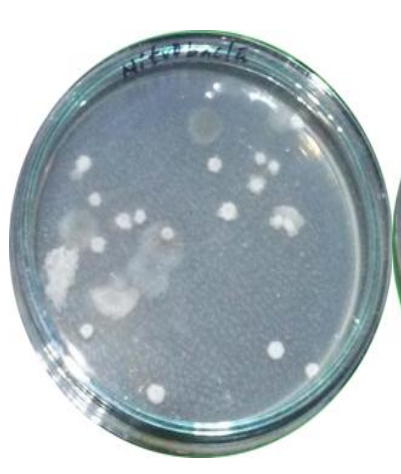

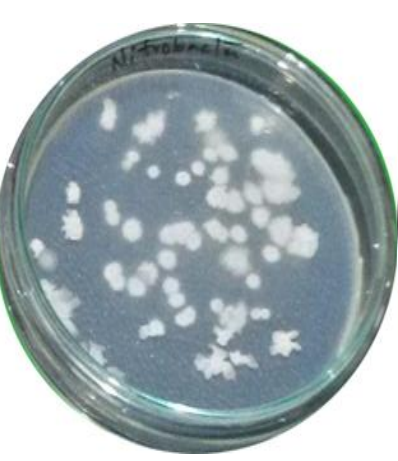

T3

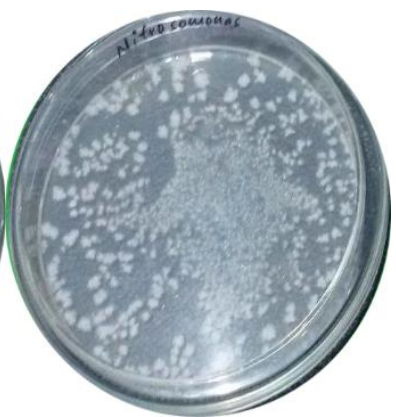




\section{c. Pseudomonas population}
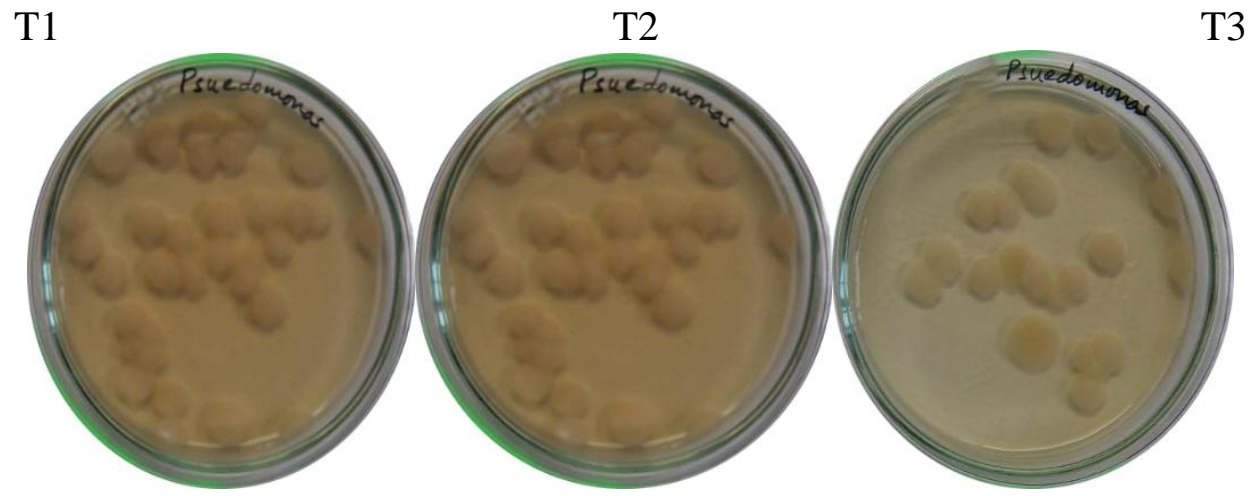

It is obvious from the bacterial load data that the Nitrosomonas and Nitrobacter species were hegemonized and suppresses the Pseudomonas sp. in the probiotic treated ponds when compared to the control pond (Fernandez et al., 2011). As a result of probiotic activity, water quality improved and reduce the organic matter load. Nitrifying bacteria also reduced, which lead to good water quality. In the present study, Nitrosomonas and Nitrobacter loads in T2, T3 and control ponds ranged respectively from $2.96 \times 10^{4}$ to $4.58 \times 10^{4} \mathrm{cfu} / \mathrm{ml}, 2.89 \times 10^{4}$ to $5.62 \times 10^{4} \mathrm{cfu} / \mathrm{ml}$ and $1.20 \times 10^{4}$ to $2.0 \times 10^{4}$ $\mathrm{cfu} / \mathrm{ml}$ and $2.80 \times 10^{4}$ to $3.72 \times 10^{4}, 2.56 \times 10^{4}$ to $5.50 \times 10^{4}$ and $1.76 \times 10^{4}$ to $1.0 \times 10^{4}$. As the T1 and T2 is treated with probiotics having Nitrosomonas and Nitrobacter species, their abundance in these ponds can be explained. These bacterial loads were also observed to be gradually increasing by the end of the culture period. As these bacteria are known to convert ammonia to nitrite and then to nitrate, low levels of ammonia and nitrite observed (Table 1) in T2 and T3 compared to control pond can be supported.

Fish diseases are one of the major problems in the fish farming industry. Freshwater fish in Indian ponds commonly suffer from bacterial diseases such as various kinds of skin ulcerations including the most dreaded Epizootic ulcerative syndrome (EUS), albinoderma, erythroderma, tail and fin rot and hemorrhagic septicemia, primarily caused by Aeromonasspp. and Pseudomonas spp. (Das, 2004). Pond fertilization using high amounts of animal wastes are known to have caused noticeable harm to the environment (Quines, 1998), by proliferating the growth of pathogenic bacteria like Aeromonassp. and Pseudomonas species. in the water body (Hojovec, 1977; Sugita et al. 1985; Jinyiet al. 1987). In the present study, Pseudomonas loads in T2 and T3 ranged from $1.05 \times 10^{5}$ to $2.75 \times 10^{5} \mathrm{cfu} / \mathrm{ml}$ and $1.01 \times 10^{5}$ to $2.90 \times 10^{5} \mathrm{cfu} / \mathrm{ml}$ and in control pond from $3.20 \times 10^{5}$ to $7.56 \times 10^{5} \mathrm{cfu} / \mathrm{ml}$. It was observed that Pseudomonas loads showed changing patterns from sampling to sampling with decreasing trend to the end of the culture period. Even though vaccines are being developed and marketed, they cannot be used as a universal disease control measure in aquaculture. The use of antibiotics to cure bacterial infection and prevent fish mortality in aquaculture is becoming limited as pathogens develop resistance to the drugs (Gonzalez et al., 2000)

The result of biochemical characterization of the bacterial isolates. Three bacterial isolates were obtained from samples collected and analyzed (water). In biochemical analyses 
carried out on the isolates, the probable identity of each genera include: Nitosomonas species was gram negative rod, methyl red positive, oxidase positive, hydrogen sulfide positive and indole negative. Nitrobacter species was gram negative rod, methyl red positive, oxidase positive, hydrogen sulfide positive and indole negative. Pseudomonas species was gram negative rod, voges-proskauer negative, indole negative, methyl red negative and catalase positive The probably identity of isolates are Nitosomonas species, Nitrobacter species and Pseudomonas species with reference to Bergey's manual of determinative bacteriology.

In conclusion, the probiotics played a major role in maintaining water quality parameters and bacterial load data that the Nitrosomonas and Nitrobacter species were dominated and suppressed the Pseudomonas species in the probiotic used ponds when compared to the control pond. The isolated probiotic bacteria was identified by morphology and biochemical characterization.

\section{Acknowledgements}

One of the authors, K. Sunitha is thankful to the UGC for providing financial assistance under the Rajiv Gandhi National Fellowship. Authors are grateful to the authorities of Acharya Nagarjuna University for providing necessary laboratory facilities.

\section{References}

APHA, 1999. Standard methods for the examination of water and wastewater (c). $20^{\text {th }}$ edition. Washington: American Public Health Association, American Water Works Association, and Water Pollution Control Federation. Aquacult. Eng., 13: 115-
128.

Ahmed, H., Al-Harbi, T., Uddin, M.N. 2005. Bacterial diversity of tilapia (Oncorhynchus mykiss) cultured in brackish water in Saudi Arabia. Aquaculture, 250:566-572.

Austin, B and Day, J.G. 1990. Inhibitition of prawn pathogenic Vibro spp. By a commercial spray-dried preparation of Tetrasel missuecica. Aquaculture. 90:389-392

Cappuccino, J.G. and Sherman, N. 1996. Microbiology- a Laboratory Manual, pp. 137-49. The Benjamin/ Cummings Pub. Co. Inc. New York, USA.

Chen, S. and $\mathrm{Hu}$, Y. 2011. Use of bacillus subtillus in purification of slightlypolluted water. Acta Scienctiae Circumstantiae, 31(8):1594-1601.

Das, B.K. 2004. Bacterial diseases of fish and their control [A]. In: Swain P. Sahoo, P.K., Das, B.K. Disease diagnosis and Health Management of freshwater fish and Shell fish ([M]. Bhubaneshwar: Central Institute of Freshwater Aquaculture, 45-52.

Fernandez, R., Sridhar, M., Sridhar, N. 2011. Effect of lactic acid bacteria administered orally on growth performance of Penaeusindicus $(\mathrm{H}$. Milne Edwards) juveniles. Res. J. Microbiol., 6(5): 466-479.

Gomez-Gil, B., Roque, A. and Turnbell, J.E. 2000. The use and selection of probiotic bacteria for use in the culture of larval aquatic organisms. Aquaculture, 191: 259-270.

Gonzalez, C.J., Encians, J.P., Garcia-Lopez, M.L. and Otero, A. 2000. Characterization and identification of lactic acid bacteria from freshwater fishes. Food Microbiol., 17: 383-391.

Hojovec, J. 1977. Health effects from waste utilization ([A]. In: Taiganides EP. Animal Wastes [M]. London: Applied Science Publishers Limited, 105-109. 
Holt, G., Jhon Noel, R., Krieg, Petyer, H.A., Sneath, James T., Staley, Stanle, T.1994. Williams Bergey's manual of determinative bacteriology. $9^{\text {th }}$ edition. Lippincott Willians\& Wilkins, AWolters Kluwer Company. 559-562.

Jinyi, D., Xianzhen, G., Xiuzhen, F. and Meizhen L. 1987. Preliminary studies on the effect of animal manure on bacterial disease of fish (M), NACA Working paper No.49. Bangkok: Network of Aquaculture centers in Asia-Pacific.

Kim, D.M., Brunt, J., Austin, B. 2007. Microbial diversity of intestinal contents andmucus in rainbow trout. (Oncorhynchusmykiss). J. Appl. Microbiol., 102:1654-1664.

Lakshmi, B., Viswanath, B. and SaiGopall, D.V.R. 2013. Probiotics as Antiviral Agents in shrimp aquaculture journal of pathogens, Article ID 424123:13 pp

Moriarty, D.J.W., Decamp, O. and Lavens, P. 2005. Probiotics in aquaculture September/ October, AQUA culture Asian Pacific magazine.

Munro, P.D., Barbour, A., Birkbeck, T.H. 1995. Comprarision of the growth and larval turbot in the absence of culturable bacteria with those in the presence of Vibrio anguillarum, Vibrio alginolyticus, or a marine Aeromonass sp. Appl. Environ. Microbial., 61: 4425-4428.

Ninawe, A.S., and Selvin, J. 2009. Probiotics in shrimp aquaculture: avenues and challenges. Crit. Rev. Microbiol., 35(1): 43-66. Doi: 10.1080/10408410802667202.

Quines, O.D. 1998. Microorganisms: indicator of pollution in integrated livestock-fish farming systems. $J$. Environ. Int., 14: 531-534.

Sugita, H., Ushioka, S., Kihara, D. and Deguchi, Y. 1985. Changes in the bacterial composition of water of carp rearing tank [J]. Aquaculture, 44: 243247.

Verma, G. and Gupta, A. 2015. Probiotic application in aquaculture: improving nutrition and health. J. Anim. Feed Sci. Tech., 3: 53-64.

Verschuere, L., Rombaut, G., Sorgeloos, P. and Verstraete, W. 2000. Probiotic bacteria as biological control agents in aquaculture. Microbiol. Mol. Biol. Rev., 64: 655-671.

\section{How to cite this article:}

Sunitha, K., and Krishna, P.V. 2016. Efficacy of Probiotics in Water Quality and Bacterial Biochemical Characterisation of Fish Ponds. Int.J.Curr.Microbiol.App.Sci. 5(9): 30-37. doi: http://dx.doi.org/10.20546/ijcmas.2016.509.004 